\title{
ARTIKELEN
}

\section{De arbeidsmarktintegratie van jongeren in Europa verklaard}

\author{
Marloes de Lange, Maurice Gesthuizen \& Maarten H.J. Wolbers*
}

\begin{abstract}
Jongeren in Europa worden momenteel met grote moeilijkheden geconfronteerd tijdens hun arbeidsmarktintrede. Het percentage jongeren dat werkloos is of in een tijdelijke baan werkt, is groot, hoewel er aanzienlijke verschillen zijn in arbeidsmarktintegratie tussen Europese landen. In dit artikel bestuderen we in hoeverre cyclische, structurele en institutionele factoren landenverschillen in de arbeidsmarktintegratie van jongeren verklaren. Daarnaast onderzoeken we of er verschillen naar opleidingsniveau zijn in de effecten van deze macrokenmerken. Voor het beantwoorden van deze vragen maken we gebruik van gegevens over jongeren uit 29 Europese landen, die in het kader van het European Social Survey in het jaar 2002, 2004, 2006 of 2008 zijn ondervraagd en in de periode 1992-2008 het dagonderwijs hebben verlaten. De resultaten van de empirische analyse laten allereerst zien dat een hoge werkloosheid jongeren weerhoudt van een soepele integratie op de arbeidsmarkt. Daarnaast heeft economische globalisering een positief effect op de arbeidsmarktintegratie van jongeren. Ook is aangetoond dat de arbeidsmarktintegratie van jongeren makkelijker verloopt naarmate het onderwijssysteem meer beroepsgericht is. Dit werkt vooral in het voordeel van hoger opgeleide jongeren. Ten slotte ondervinden jongeren meer moeilijkheden bij hun arbeidsmarktintegratie naarmate zittende werknemers meer ontslagbescherming genieten. Dit geldt met name voor hoger opgeleide jongeren.
\end{abstract}

\section{Inleiding}

Arbeidsmarktintegratie van jongeren in Europa

De intrede van jongeren op de arbeidsmarkt gaat momenteel gepaard met grote moeilijkheden. Niet alleen de jeugdwerkloosheidscijfers zijn hoog in veel landen, ook het aandeel jongeren in flexibele arbeid, zoals tijdelijke banen of uitzendbanen, is groot. In 2011 was in Europa meer dan een op de vijf jongeren onder de 25 jaar werkloos en hadden zelfs twee van de vijf werkende jongeren een tijdelijke baan (OECD, 2012). Dat werkloosheid tot grote onzekerheid op de arbeidsmarkt leidt, ligt voor de hand, maar ook voor flexibele banen geldt dat zij weinig arbeidsmarktperspectief en -zekerheid bieden ten opzichte van vaste banen met een vast

* Marloes de Lange is werkzaam bij de Radboud Universiteit Nijmegen, Sectie Sociologie, emailadres: m.delange@maw.ru.nl. Maurice Gesthuizen is werkzaam bij de Radboud Universiteit Nijmegen, Sectie Sociologie. Maarten H.J. Wolbers is werkzaam bij de Radboud Universiteit Nijmegen, Sectie Sociologie. 
inkomen (Delsen \& De Jong, 1997; Scherer, 2005). Zo is het bijvoorbeeld onzeker of men een jaar later nog (steeds) aan het werk is en voor hoeveel uur, en daarmee is ook de hoogte van het inkomen in de nabije toekomst onbekend. Daarnaast veroorzaakt flexibele arbeid in de vroege loopbaan mogelijk structurele problemen bij jonge individuen: men kan blijven hangen in dergelijke onzekere banen in de verdere loopbaan, wat kan leiden tot uitsluiting van actieve participatie op de arbeidsmarkt en als gevolg daarvan zelfs tot armoede (Scherer, 2005; Steijn et al., 2006). Ook worden beslissingen zoals de aanschaf van een huis of met betrekking tot gezinsvorming mogelijk uitgesteld vanwege onzekerheid in de vroege loopbaan (Mills \& Blossfeld, 2005). De gevolgen van een gebrekkige arbeidsmarktintegratie, zowel in de zin van flexibele arbeid als werkloosheid, kunnen jongeren dus langdurig blijven achtervolgen.

Hoewel de overgang van school naar werk tegenwoordig niet erg soepel verloopt en jongeren veel onzekerheid ervaren bij hun intrede op de arbeidsmarkt, zijn er grote verschillen in arbeidsmarktintegratie tussen Europese landen. Vooral in Zuid-Europa is de jeugdwerkloosheid alarmerend hoog: in Portugal en Italië is bijna een derde van de jongeren onder de 25 jaar werkloos; in Spanje en Griekenland heeft zelfs de helft van de jongeren geen werk. Tijdelijk werk onder schoolverlaters in Spanje en Portugal ligt rond de 45 procent. Ook in Oost-Europa brengt de integratie van jongeren op de arbeidsmarkt veel onzekerheid met zich mee, met werkloosheidscijfers van meer dan 25 procent in Polen en Hongarije, bijvoorbeeld. Van alle Poolse schoolverlaters die een baan vinden, is deze baan in de helft van de gevallen een tijdelijke. In andere delen van Europa verloopt de arbeidsmarktintegratie van jongeren iets soepeler: de werkloosheid onder jongeren in Nederland en Zwitserland, bijvoorbeeld, bedraagt zo'n 10 procent. Ook in andere West- en Noord-Europese landen, zoals Oostenrijk, Duitsland en Noorwegen, zijn deze cijfers relatief laag en zijn ze niet sterk toegenomen in het laatste decennium. Tegelijkertijd is echter het aandeel schoolverlaters met een tijdelijke baan soms erg hoog in deze landen: in zowel Nederland als Duitsland heeft vandaag de dag een op de drie jonge werknemers een tijdelijke aanstelling.

Cyclische en structurele verklaringen voor landenverschillen in arbeidsmarktintegratie Macro-economische omstandigheden spelen een belangrijke rol bij het verklaren van verschillen in arbeidsmarktintegratie van jongeren tussen landen (Blanchard, 2006; Gangl, 2002; OECD). Als het algehele werkloosheidscijfer in een land hoog is, dan is door de bank genomen ook de jeugdwerkloosheid in dat land hoog. Er zit ongeveer een factor twee tussen, in het nadeel van de jongeren. Toch zijn er duidelijke landenverschillen in de verhouding tussen beide werkloosheidspercentages. In het ene land zijn jongeren relatief vaker dan ouderen werkloos dan in het andere. In Italië, bijvoorbeeld, lopen jongeren 3,5 keer meer risico op werkloosheid dan ouderen, terwijl deze ratio in Duitsland 1,5 bedraagt. Dit duidt erop dat de jeugdwerkloosheid in een land van meer afhangt dan de stand van de conjunctuur alleen. Blossfeld et al. (2008), bijvoorbeeld, beargumenteren dat ook structurele processen zoals economische globalisering hebben geleid tot meer moeilijkheden en onzekerheid bij de arbeidsmarktintrede van jongeren. Veel ander onder- 
zoek echter benadrukt de rol van nationale institutionele kaders voor het verklaren van landenverschillen in de arbeidsmarktintegratie van jongeren.

\section{De rol van institutionele kenmerken}

Voor wat betreft het onderwijssysteem hebben verschillende onderzoekers de invloed van de beroepsgerichtheid ervan op de arbeidsmarktintegratie van jongeren in Europa bestudeerd (zie bijv. Bol \& Van de Werfhorst, 2013; Breen, 2005; Golsch, 2008; Van der Velden \& Wolbers, 2003; Wolbers, 2007). In deze studies tonen zij overtuigend aan dat de intredekansen van jongeren op de arbeidsmarkt beter zijn in landen waar het onderwijssysteem een kwalitatief uitgebreid stelsel van beroepsonderwijs kent waarin beroepsgerichte opleidingen deelnemers kennis en vaardigheden bijbrengen die hen specifiek voorbereiden op een beperkt aantal beroepen. Daarnaast laten deze studies zien dat werkgelegenheidsbeschermende wet- en regelgeving van zittende werknemers de intredekansen van schoolverlaters ondermijnt. In Europese landen waar de rechtspositie van zittende werknemers wordt beschermd (ofwel landen die een weinig soepel ontslagrecht kennen), verloopt de integratie van jongeren op de arbeidsmarkt moeizamer dan in landen waar dit niet het geval is.

\section{Opleidingsspecifieke invloeden van cyclische, structurele en institutionele factoren?}

Ook zijn er enkele studies verschenen die aangeven dat er verschillen naar opleiding zijn in de invloed van cyclische, structurele en institutionele factoren op de arbeidsmarktintegratie van jongeren. Zo liet Gangl (2002) zien dat de laagst gekwalificeerde nieuwkomers op de arbeidsmarkt het meest te lijden hebben onder veranderingen in de conjuncturele cyclus. Daarnaast toonden De Grip en Wolbers (2006) aan dat in Europese landen waar een institutionele koppeling bestaat tussen het onderwijssysteem en de arbeidsmarkt, laagopgeleide jongeren minder vaak een vaste baan hebben dan in landen waar een geringe band bestaat tussen het onderwijs en de arbeidsmarkt, omdat in eerstgenoemde landen de toegang tot vaste banen veel restrictiever is voor individuen die niet over het benodigde niveau van (beroepsspecifieke) kennis en vaardigheden beschikken. Ten slotte concludeerde ook Wolbers (2007) dat de invloed van de door hem onderzochte institutionele factoren verschilt tussen opleidingsniveaus. Het nadelige effect van werkgelegenheidsbeschermende wet- en regelgeving speelt vooral hoger opgeleiden parten bij het vinden van een eerste baan na schoolverlaten, terwijl de beroepsgerichtheid van het onderwijssysteem vooral lager opgeleiden helpt bij het vinden van een eerste baan.

\section{Onderzoeksvragen en bijdrage aan de literatuur}

In dit artikel bouwen we voort op het bovengenoemde onderzoek door de invloed van cyclische, structurele en institutionele factoren op de arbeidsmarktintegratie van jongeren in maar liefst 29 Europese landen te bestuderen. Het betreft jongeren die in de periode tussen 1992 en 2008 het dagonderwijs hebben verlaten en in het kader van het European Social Survey (ESS) in het jaar 2002, 2004, 2006 of 2008 zijn ondervraagd. Onze onderzoeksvragen zijn als volgt: In hoeverre verklaren cyclische, structurele en institutionele factoren verschillen in de arbeidsmarktinte- 
gratie van jongeren in Europa, sinds de jaren negentig? En in welke mate zijn deze effecten opleidingsspecifiek? We boeken in een viertal (methodologische) opzichten vooruitgang op het eerdere onderzoek.

In de eerste plaats kunnen we hier een vergelijking maken van een veel groter aantal landen dan in eerder onderzoek mogelijk was, waaronder ook Centraal- en Oost-Europese landen. Het belang van het bestuderen van postsocialistische landen in vergelijkend onderzoek naar de arbeidsmarktintegratie van jongeren werd recentelijk nog benadrukt in een studie naar transities van school naar werk (Kogan et al., 2011). Meer in het algemeen resulteert dit in een veel krachtigere en nauwkeurigere statistische toetsing van de opgestelde hypothesen en een verdere generalisatie van eerdere onderzoeksresultaten. In de tweede plaats kunnen we nu, door het grote aantal landen waarover gegevens beschikbaar zijn, de invloed van cyclische, structurele en institutionele factoren simultaan schatten. Hierdoor wordt het relatieve belang van deze macrokenmerken op de arbeidsmarktintegratie van jongeren in Europa adequaat vastgesteld. In de derde plaats biedt het grote aantal landen in de empirische analyse de mogelijkheid om zogenoemde crossniveau-interacties tussen de onderscheiden cyclische, structurele en institutionele factoren enerzijds en het opleidingsniveau van jongeren anderzijds te schatten. Hoewel dit in enkele eerdere studies ook al is gedaan, is het onderscheidingsvermogen van de statistische toetsing hier veel groter. In de vierde plaats hanteren we een meer allesomvattende definitie van arbeidsmarktintegratie van jongeren. We beschouwen tijdelijk werk en werkloosheid als concurrerende alternatieven voor het ideaal van vast werk in dit artikel en analyseren deze drie uitkomsten daarom simultaan. Daarmee willen we niet suggereren dat tijdelijk werk en werkloosheid gelijkwaardig zijn aan elkaar; enkel stellen we dat beide minder gunstig zijn ten opzichte van een vaste baan. Eerder onderzoek richtte zich steeds op een van beide maten voor de arbeidsmarktintegratie van jongeren, zonder de samenhang tussen beide in ogenschouw te nemen.

\section{Theorie en hypothesen}

\section{Economisch klimaat en arbeidsmarktintegratie van jongeren}

De economische crisis die sinds 2008 voortduurt, heeft tot een hoge werkloosheid geleid in Europa. Er bestaat overigens wel een groot verschil tussen landen. In Griekenland en Spanje bereiken de werkloosheidscijfers thans de 25 procent, terwijl in Nederland, bijvoorbeeld, het huidige werkloosheidspercentage zo'n 6 procent is. Het belangrijkste gevolg van deze economische neergang voor bedrijven is de toegenomen onzekerheid over hun afzetmarkt. Over het algemeen proberen zij deze onzekerheid af te wentelen op het personeel. Dit kan bijvoorbeeld worden bereikt door het instellen van tijdelijke arbeidscontracten in plaats van langlopende contractuele verplichtingen aan te gaan met hun (toekomstige) werknemers. Deze vorm van flexibele arbeid geeft werkgevers in economisch mindere tijden de mogelijkheid werknemers net zo lang vast te houden als ze nodig zijn en te ontslaan zodra ze overbodig zijn. Als er al banen gecreëerd worden tijdens een economische crisis, zijn dit dus vooral tijdelijke in plaats van vaste banen, maar 
het is daarnaast aannemelijk dat werkgevers überhaupt minder banen aanbieden tijdens een economische crisis, waardoor ook de kans op werkloosheid toeneemt ten koste van de kans op een vaste baan. Zoals we eerder hebben gesteld, volgt het patroon van jeugdwerkloosheid binnen landen over het algemeen dat van de werkloosheid in de totale beroepsbevolking, maar is het werkloosheidspercentage onder jongeren beduidend hoger. We kunnen dus veronderstellen dat jongeren een grotere kans hebben op tijdelijk werk of werkloosheid in de vroege loopbaan ten opzichte van vast werk naarmate de werkloosheid hoger is (H1a). Maar waarom worden juist jongeren zo sterk getroffen door een economische crisis? Het antwoord is dat zij door werkgevers als outsiders op de arbeidsmarkt worden gezien. Het ontbreekt jongeren bij het betreden van de arbeidsmarkt aan ervaring, anciënniteit, lobby en relevante netwerken, wat hen minder aantrekkelijk maakt voor werkgevers vergeleken met zittende werknemers (Bukodi et al., 2008; De Vreyer et al., 2001).

Over het algemeen ondervinden alle jongeren dus meer moeilijkheden bij het betreden van de arbeidsmarkt tijdens een economische recessie, maar er bestaan aanwijzingen dat deze problemen niet voor iedere jongere even groot zijn. Breen (1997) stelt dat het voor de beslissing van een werkgever een werknemer een vaste aanstelling aan te bieden uitmaakt in hoeverre hij deze kan controleren bij de werkzaamheden die moeten worden verricht. Werknemers in banen waarvoor hoge kwalificaties zijn vereist, zijn moeilijk aan directe supervisie te onderwerpen door de gespecialiseerde kennis en vaardigheden van degenen die deze banen uitoefenen. Dergelijke banen worden, in vergelijking met banen die minder kwalificaties verlangen, vaker in vaste dienst aangeboden, zelfs in economisch zeer onzekere tijden. Hogere banen vereisen meer opleiding en daardoor een grotere investering van werkgevers in hun werknemers vergeleken met lagere banen waar werknemers gemakkelijker kunnen worden vervangen. Het is dus voor het invullen van vacatures van hogere banen minder voordelig personeel slechts voor een korte duur in dienst te nemen. Evenzeer zijn voor hogere banen de voordelen voor werkgevers van een langdurige binding met hun werknemers in goede economische tijden substantieel groter dan de voordelen van flexibiliteit in werkrelaties tijdens een economische recessie (Breen, 1997, p. 480). Omdat zulke banen alleen beschikbaar zijn voor hoger opgeleiden, zullen hoger opgeleide jongeren beter beschermd zijn tegen de negatieve gevolgen van een hoge werkloosheid voor wat betreft hun arbeidsmarktintegratie dan lager opgeleide jongeren.

Een bijkomende reden waarom hoger opgeleide jongeren zich in een betere arbeidsmarktpositie bevinden gedurende een economische recessie, is dat zij kunnen uitwijken naar banen onder hun niveau als het banenaanbod onvoldoende is om alle hoogopgeleide schoolverlaters op hun niveau aan het werk te helpen. Voor lager opgeleide schoolverlaters is het daarentegen moeilijker, en voor de laagst opgeleiden logischerwijs zelfs onmogelijk, een baan te accepteren onder hun opleidingsniveau. Zij lopen daarom een groter risico op flexibele arbeid of werkloosheid. Dit proces wordt omschreven als verdringing (Borghans \& De Grip, 2000; Gesthuizen \& Wolbers, 2010; Pollmann-Schult, 2005). Samengevat luidt de volgende hypothese daarom als volgt: het positieve effect van het werkloosheids- 
percentage op de kans op tijdelijk werk of werkloosheid ten opzichte van vast werk in de vroege loopbaan is groter voor lager dan hoger opgeleiden (H1b).

\section{Economische globalisering en arbeidsmarktintegratie van jongeren}

Het economische klimaat kan fluctuaties door de jaren heen verklaren in de mate waarin werkgevers onzekerheid ervaren en deze overdragen op hun (toekomstige) werknemers, wat leidt tot niet-lineaire ontwikkelingen in de arbeidsmarktintegratie van jongeren. De structurele ontwikkelingen in de laatste decennia voorspellen echter een onophoudelijke groei van economische onzekerheid bij de toegang tot de arbeidsmarkt, dit wil zeggen, als gevolg van het proces van economische globalisering. Globalisering kan worden opgesplitst in verschillende dimensies: economische, socio-technologische, culturele en politieke globalisering (Buchholz et al., 2009; Mills \& Blossfeld, 2005; zie ook De Lange et al., 2012). Elke dimensie is gebaseerd op een specifiek macroproces. Economische globalisering wordt meestal gezien als de centrale dimensie van globalisering en verwijst naar de internationalisering van markteconomieën en de stijgende belastingconcurrentie tussen welvaartsstaten. Vooral na de val van het IJzeren Gordijn in 1989, dat het communistische Oostblok herenigde met het kapitalistische Westen, nam de interactie tussen Europese landen met uiteenlopende loon-, sociale en productieniveaus toe. Dit leidde tot een verscheidenheid van spelers in verschillende markten, gevolgd door groeiende onderlinge competitie. Zowel corporaties als nationale staten werden geconfronteerd met nieuwe uitdagingen, zoals een harde belastingconcurrentie. De internationalisering van markten betekent dus een afname van nationale grenzen: landen gingen wereldwijde samenwerkingsverbanden aan en werden het eens over de ontwikkeling van gemeenschappelijke wetgevingen, instituties en praktijken die het eenvoudiger en goedkoper maken om grenzen te overschrijden met goederen, diensten, arbeid en kapitaal. De toenemende mondiale competitie biedt mogelijkheden aan corporaties om een sterke positie te veroveren in de wereldeconomie, maar leidt ook tot meer onzekerheid bij werkgevers door de noodzaak van snelle prijsaanpassingen van goederen en diensten aan de fluctuaties in vraag en aanbod. Dit vereist ook een flexibel personeelsbestand. Werkgevers hebben op deze ontwikkelingen ingespeeld door meer flexibele of atypische arbeidscontracten aan te bieden, zoals tijdelijke contracten (Kalleberg, 2009). Vooral nieuwkomers op de arbeidsmarkt worden hiermee geconfronteerd, omdat het hun aan de nodige ervaring ontbreekt in de concurrentie om beschikbare posities met zittende werknemers. Onder de toegenomen concurrentiedruk wordt arbeidsintensief productiewerk ook steeds meer uitgevoerd door machines of uitbesteed aan lagelonenlanden, wat leidt tot een afname van de werkgelegenheid. Daarom voorspellen we dat jongeren een grotere kans hebben op tijdelijk werk of werkloosheid in de vroege loopbaan ten opzichte van vast werk naarmate het niveau van economische globalisering hoger is (H2a). Ook hier kan weer worden verwacht dat de toenemende onzekerheid die gepaard gaat met economische globalisering, grotere nadelige consequenties heeft voor lager opgeleide jongeren die de arbeidsmarkt voor het eerst betreden dan voor hoger opgeleide jongeren. Zoals eerder gezegd is het moeilijker individuen in hogere banen te onderwerpen aan directe supervisie en hen te vervangen door 
nieuwe werknemers, waardoor hoger opgeleiden vaker beloond worden met een vaste aanstelling, ook als de arbeidsmarkt sterk onderhevig is aan onzekerheden en risico's (Breen, 1997). Daarnaast is er, zoals aangegeven, vaak sprake van neerwaartse verdringing (Borghans \& De Grip, 2005; Gesthuizen \& Wolbers, 2010; Pollmann-Schult, 2000). Hoger opgeleiden kunnen immers gemakkelijker uitwijken naar banen onder hun niveau dan lager opgeleiden. En voor de laagst opgeleiden geldt zelfs dat zij niet onder hun niveau werkzaam kunnen zijn, maar worden geconfronteerd met werkloosheid of inactiviteit.

Er is echter nog een reden waarom wordt verwacht dat hoger opgeleide jongeren bij het betreden van de arbeidsmarkt minder last hebben van economische globalisering. Het feit dat bedrijven mondiaal competitief zijn geworden en markteconomieën steeds internationaler, is mogelijk gemaakt door technologische ontwikkelingen, zoals de introductie van microcomputers en het internet (Kalleberg, 2009). Dankzij deze nieuwe technologieën en de moderne massamedia wordt de verspreiding van informatie en kennis amper vertraagd of beperkt door tijd en plaats (Castells, 1996). Deze technologische innovatie heeft geleid tot veranderingen in het arbeidsproces, met name tot een toenemende behoefte aan kennisintensieve arbeid (Berman et al., 1998). Meer bepaald heeft de dienstensector zich erg uitgebreid, ten koste van de traditionele sectoren landbouw en industrie. Deze herstructurering van de arbeidsmarkt betekende een verschuiving in de vraag naar arbeid van laag- naar hooggeschoold werk, wat ook wel bekend staat als skillbiased technological change (Katz \& Autor, 1999). Als gevolg hiervan is het aantal arbeidsplaatsen waarvoor een hoge opleiding nodig is, flink toegenomen, terwijl laag- of ongeschoolde arbeid steeds meer verdwenen is of uitbesteed aan lagelonenlanden. Hierdoor is de positie van lager opgeleiden op de arbeidsmarkt over het algemeen verslechterd. Deze argumenten samen leiden tot de verwachting dat het positieve effect van economisch globalisering op de kans op tijdelijk werk of werkloosheid ten opzichte van vast werk in de vroege loopbaan groter is voor lager dan hoger opgeleiden (H2b).

\section{Beroepsgerichtheid van het onderwijssysteem en arbeidsmarktintegratie van jongeren}

Eerder onderzoek toonde duidelijk aan dat de toegang tot de arbeidsmarkt voor schoolverlaters beïnvloed wordt door de structuur van het onderwijssysteem in een land (Allmendinger, 1989; Hannan et al., 1997; Müller \& Gangl, 2003; Shavit \& Müller, 1998). Een belangrijk aspect hierbij is de institutionele koppeling tussen het onderwijs en de arbeidsmarkt. Daarbij wordt een onderscheid gemaakt tussen een qualificational space en een organizational space (Maurice \& Sellier, 1979). Dit onderscheid is gebaseerd op de wijze waarop in het onderwijssysteem van een land theoretisch leren wordt gecombineerd met praktische werkervaring. In landen met het eerstgenoemde systeem is het onderwijsprogramma vooral algemeen of academisch van aard. Hier worden specifieke beroepsvaardigheden niet al in het onderwijs aangeleerd, maar pas verworven in de praktijk. Dit impliceert dat de link tussen het onderwijs en de arbeidsmarkt relatief zwak is in deze landen. Daartegenover staat dat in andere landen beroepsspecifieke vaardigheden al in het onderwijs worden aangeleerd via beroeps- of vakonderwijs. Schoolverlaters zijn daardoor beter voorbereid op de beroepspraktijk en behoeven minder 
aanvullende training. Dit maakt hen aantrekkelijker voor werkgevers (Blossfeld, 1992). In deze landen bestaat een nauwe band tussen het onderwijs en de arbeidsmarkt en nemen diploma's en certificaten een belangrijke plaats in (Mills \& Blossfeld, 2005; Wolbers, 2007).

De manier waarop deze nauwe band is geïnstitutionaliseerd, verschilt van land tot land. Beroepsonderwijs kan worden georganiseerd door 'theoretische' training in vakscholen (zoals in Nederland), door 'praktische' training op de werkvloer (zoals in Ierland) of door een combinatie van beide, ook wel het 'duaal' stelsel van werken en leren genoemd (zoals in Duitsland). Vooral dit laatste systeem biedt voordelen, zowel voor werkgevers als toekomstige werknemers. Zo kunnen werkgevers potentiële werknemers al in een vroeg stadium beoordelen op hun (te verwachten) capaciteiten, terwijl een stage toekomstige werknemers de gelegenheid biedt alvast een kijkje in de keuken te nemen en enige werkervaring op te doen (Wolbers, 2007). Wanneer er sprake is van positieve indrukken van beide partijen, dan is de kans aannemelijk dat een schoolverlater op de leerwerkplek blijft werken na afronding van de beroepsopleiding en een vaste baan krijgt aangeboden. De kans dat hij werkloos wordt na schoolverlaten of zich eerst nog moet bewijzen in een tijdelijke baan, neemt daarmee dus af, omdat dit stadium in feite al tijdens de schoolgaande periode doorlopen wordt. In het kort verwachten wij daarom dat jongeren een kleinere kans hebben op tijdelijk werk of werkloosheid in de vroege loopbaan ten opzichte van vast werk naarmate het onderwijssysteem meer beroepsgericht is (H3a).

In landen met een beroepsgericht onderwijssysteem, waar het belang van het bezit van de juiste diploma's en certificaten dus groot is, kan worden verwacht dat de arbeidsmarktintegratie vooral soepel verloopt voor jongeren met een beroepsopleiding, die ook daadwerkelijk deze diploma's bezitten en dus de kennis en vaardigheden zouden moeten bezitten, die door werkgevers beloond worden met vaste banen (de Grip \& Wolbers, 2006; Wolbers, 2007). Anders gezegd: laagopgeleide schoolverlaters zijn slechter af in landen waarin diploma's een sterk informatieve functie hebben voor werkgevers. Dit verklaart echter niet direct waarom de diploma's van hoger opgeleiden ook beter beloond worden in landen met een beroepsgericht onderwijssysteem. In dergelijke landen is de deelname aan het hoger onderwijs gewoonlijk minder groot, omdat onderwijs daar minder sterk als een positioneel goed wordt beschouwd, dan in landen met een onderwijssysteem dat vooral algemeen vormend van aard is, waar het volgen van steeds meer onderwijs een meer rationele keuze is van individuen, wat tot onderwijsexpansie leidt op nationaal niveau. In landen met een beroepsgericht onderwijssysteem kent het hoger onderwijs dus een meer exclusief karakter, wat de arbeidsmarktkansen van afgestudeerden ten goede komt. Voor zowel middelbaar als hoger opgeleiden zou de arbeidsmarktintegratie dus soepeler moeten verlopen in landen met een beroepsgericht onderwijssysteem, terwijl het voor lager opgeleiden mogelijk zelfs moeilijker is om een vaste baan te vinden in dergelijke landen, omdat de toegang tot zulke banen veelal beperkt is voor individuen die niet over de juiste papieren beschikken (De Grip \& Wolbers, 2006). Daarom is onze hypothese dat het negatieve effect van de beroepsgerichtheid van het onderwijssysteem op de kans op 
tijdelijk werk of werkloosheid ten opzichte van vast werk in de vroege loopbaan groter is voor middelbaar en hoger dan lager opgeleiden (H3b).

\section{Werkgelegenheidsbeschermende wet- en regelgeving en arbeidsmarktintegratie van jongeren}

Tot slot kunnen nationale verschillen in werkgelegenheidsbeschermende wet- en regelgeving op de arbeidsmarkt verklaren waarom de arbeidsmarktintegratie van jongeren varieert in Europa. Gesteld wordt dat deelnemers op de arbeidsmarkt onderverdeeld kunnen worden naar insiders en outsiders (Lindbeck \& Snower, 1988). Zij die werk hebben, zijn insiders en degenen zonder werk worden beschouwd als outsiders. Een specifieke groep van outsiders wordt gevormd door nieuwkomers op de arbeidsmarkt (De Vreyer et al., 2000), omdat schoolverlaters zonder werkervaring moeten concurreren om de beschikbare banen met degenen die al een positie op de arbeidsmarkt hebben verworven. Onderhandelingen over loon vinden plaats tussen insiders en werkgevers en outsiders spelen in dit proces geen rol. Het belangrijkste doel voor zittende werknemers is aan het werk te blijven; de werkgelegenheid voor outsiders heeft geen prioriteit. Ook zetten insiders zich in voor een sterkere rechtspositie. Het verstevigen van de rechtspositie van werknemers heeft betrekking op regelgeving ten aanzien van het aannemen en ontslaan van personeel (ontslagbescherming). Over het algemeen proberen zittende werknemers hun rechtspositie te vergroten door een aantal arbeidsvoorwaarden steviger te verankeren in de wet en collectieve arbeidsovereenkomsten. Met name het anciënniteitsbeginsel is een belangrijk criterium. Gewoonlijk belet dit dat werknemers met veel dienstjaren worden ontslagen, terwijl jongeren, die als laatsten bij een bedrijf zijn komen werken, de eersten zijn die worden ontslagen wanneer het bedrijf daartoe is genoodzaakt. Vanuit dit beginsel bezien ondermijnt werkgelegenheidsbeschermende wet- en regelgeving van zittende werknemers de integratie van jongeren op de arbeidsmarkt. Zij belanden gewoonlijk in onzekere arbeidsmarktposities, waarin tijdelijk werk en werkloosheid elkaar afwisselen, of raken zelfs gevangen in langdurige werkloosheid. Landen verschillen echter in de mate waarin de rechtspositie van zittende werknemers wordt beschermd (OECD, 1999). Verondersteld wordt dat jongeren een grotere kans hebben op tijdelijk werk of werkloosheid in de vroege loopbaan ten opzichte van vast werk naarmate de ontslagbescherming van zittende werknemers sterker is (H4a).

Tot slot veronderstellen we weer verschillen naar opleidingsniveau. Hoger opgeleiden bevinden zich veelal in het primaire segment van de arbeidsmarkt waar onderhandelingen over arbeidsvoorwaarden in de regel plaatsvinden tussen vakbonden en werkgevers. Werkgelegenheidsbeschermende wet- en regelgeving is er vrij strikt. De kosten van verloop van werknemers in dit arbeidsmarktsegment zijn hoog en het is daarom duur om hen te ontslaan. Lager opgeleiden daarentegen bevinden zich meestal in het secundaire segment van de arbeidsmarkt dat minder gereguleerd is en waar werknemers minder ontslagbescherming genieten. Om die reden verwachten we dat het positieve effect van de ontslagbescherming van zittende werknemers op de kans op tijdelijk werk of werkloosheid ten 
opzichte van vast werk in de vroege loopbaan groter is voor hoger dan lager opgeleiden (H4b).

\section{Data en variabelen}

Data

Voor de empirische analyse van dit artikel gebruiken we data van het European Social Survey (ESS), verzameld in de jaren 2002, 2004, 2006 en 2008 (Jowell et al., 2003, 2005, 2007 en 2009). We analyseren gegevens van individuen afkomstig uit 29 Europese landen, te weten België (BE), Bulgarije (BG), Cyprus (CY), Denemarken (DK), Duitsland (DE), Estland (EE), Finland (FI), Frankrijk (FR), Griekenland (GR), Hongarije (HU), Ierland (IE), Israel (IL), Italië (IT), Luxemburg (LU), Nederland (NL), Noorwegen (NO), Oekraïne (UA), Oostenrijk (AT), Polen (PL), Portugal (PT), Russische Federatie (RU), Slovenië (SI), Slowakije (SK), Spanje (ES), Tsjechië (CZ), Turkije (TR), Verenigde Koninkrijk (GB), Zweden (SE) en Zwitserland (CH). In deze landen behoren alle personen vanaf 15 jaar, wonend in een huishouden, ongeacht hun nationaliteit, staatsburgerschap, taal of rechtspersoonlijkheid, tot de onderzoekspopulatie. Het ESS is een academisch gestuurd onderzoek en bevat een brede waaier van vragen betreffende onderwijs en arbeidsmarktparticipatie; vragen die essentieel zijn voor de empirische analyse van dit artikel. Door de hoge crossnationale vergelijkbaarheid van de metingen zijn de gegevens van het ESS bijzonder geschikt voor vergelijkingen tussen landen. In alle landen zijn equivalente kanssteekproeven toegepast.

Gezien de nadruk op de arbeidsmarktintegratie van jongeren beperken we ons in de analyse tot respondenten die het dagonderwijs maximaal 10 jaar voor het moment van ondervraging hebben verlaten en op dat moment tussen de 15 en 34 jaar oud waren. Respondenten die op het moment van ondervraging inactief waren (schoolgaand, niet werkzoekend, ziek/invalide, gepensioneerd, vrijwilliger, dienstplichtig militair, huisvrouw), zijn uitgesloten van de analyse. Het jaar van het verlaten van het onderwijs is berekend op basis van de lengte van iemands schoolcarrière zoals gerapporteerd door de respondenten in de vragenlijst. Gezien het feit dat de gegevens verzameld zijn in de periode 2002-2008, bestuderen we jongeren die de arbeidsmarkt voor het eerst hebben betreden in de periode 1992-2008. Na het schrappen van respondenten voor wie informatie ontbreekt voor om het even welke variabele in de multivariate analyse, bestaat de uiteindelijke steekproef uit 18.956 respondenten. Deze individuele data zijn uitgebreid met contextuele informatie op het hogere analyseniveau: de combinatie van land en jaar van schoolverlaten $(\mathrm{N}=468)$. Gezien deze geneste datastructuur maken we gebruik van multiniveau-analyse.

\section{Afhankelijke variabele}

De arbeidsmarktintegratie van jongeren wordt gemeten door een variabele die een driedeling maakt tussen vast werk, tijdelijk werk en werkloosheid. Het onderscheid tussen vast en tijdelijk werk is bepaald door respondenten te vragen of zij in hun huidige baan een arbeidscontract hadden van onbepaalde, respectievelijk 
bepaalde duur. Werkloosheid verwijst naar de situatie van respondenten die aangaven werkloos te zijn en actief op zoek te zijn naar een baan. In totaal heeft 61 procent van de respondenten een vaste baan, 28 procent heeft een tijdelijke baan en 11 procent is werkloos. Zoals in figuur 1 te zien is, verschilt deze verdeling echter sterk tussen de verschillende landen. Zo blijkt bijvoorbeeld dat in Turkije minder dan 35 procent van de jongeren een vaste baan had, gemiddeld over de periode 1992-2008, terwijl de rest werkloos was of een tijdelijke baan had. In Estland had juist 80 procent van de jongeren een vaste baan. Deze verschillen zijn groot en geven aan dat de arbeidsmarktintegratie van jongeren tussen de onderzochte Europese landen aanzienlijk verschilt. In de multivariate analyse wordt zowel tijdelijk werk als werkloosheid gezien als een gebrek aan arbeidsmarktintegratie. Beide situaties worden vergeleken met de ideale positie van vast werk.

\section{Onafhankelijke variabelen}

Het opleidingsniveau van individuen verwijst naar het hoogste opleidingsniveau waarvoor een diploma is behaald, en is ingedeeld in drie categorieën. Respondenten met een laag opleidingsniveau hebben maximaal lager secundair onderwijs afgerond (ISCED 0-2; voor NL: VMBO) (12 procent). De middencategorie verwijst naar respondenten die een opleiding in het hoger secundair onderwijs hebben behaald (ISCED 3-4; voor NL: HAVO/VWO/MBO) (45 procent). De derde categorie betreft individuen met een diploma in het hoger onderwijs (ISCED 5-6; voor NL: HBO/WO) (43 procent).

De individuele gegevens zijn aangevuld met verschillende contextuele kenmerken die verwijzen naar de cyclische, structurele en institutionele context van landen. Of preciezer, naar de combinatie van land en jaar van schoolverlaten. ${ }^{1}$ In Bijlage I zijn de minimale, maximale en gemiddelde waarden op deze kenmerken per land weergegeven, om een indruk te geven van de mate van variatie binnen en tussen landen op deze kenmerken. Het bereik van de scores op alle contextuele variabelen is gestandaardiseerd tot een schaal lopend van 0 tot 1 , welke vervolgens gecentreerd is rondom het gemiddelde voordat er in de multivariate analyse mee is gerekend. De samenhang tussen de vier contextuele kenmerken (op contextueel niveau) is getoond in Bijlage II. Als maat voor de conjuncturele cyclus is het werkloosheidspercentage gebruikt, gebaseerd op EU Labour Force Surveys en verkregen via de internationale arbeidsorganisatie ILO. Voor Luxemburg berusten de werkloosheidspercentages overigens op geregistreerde werkloosheidscijfers. In de gegevens varieert de werkloosheid tussen de 1,6 en 24,1 procent.

Het niveau van economische globalisering, als structurele arbeidsmarktfactor, is gemeten aan de hand van de economische dimensie van de KOF Index of Globalization (Dreher, 2006). Deze index bevat twee dimensies. Ten eerste refereert hij aan feitelijke economische stromen die meestal als maat voor globalisering genomen worden. Deze dimensie bevat indicatoren over handel, buitenlandse directe investeringen, portfolio-investeringen en betalingen van inkomens aan buitenlandse staatsburgers. Ten tweede houdt economische globalisering machtigingen in voor de beperkingen van handel en kapitaal; deze wijzen feitelijk op de afwezigheid van globalisering. Meer bepaald verwijst deze dimensie naar beperkingen op handel en kapitaal die gebruikmaken van verborgen importhindernissen, gemiddelde 


\section{Figuur 1 Verschillen in de arbeidsmarktintegratie van jongeren tussen Europese landen}

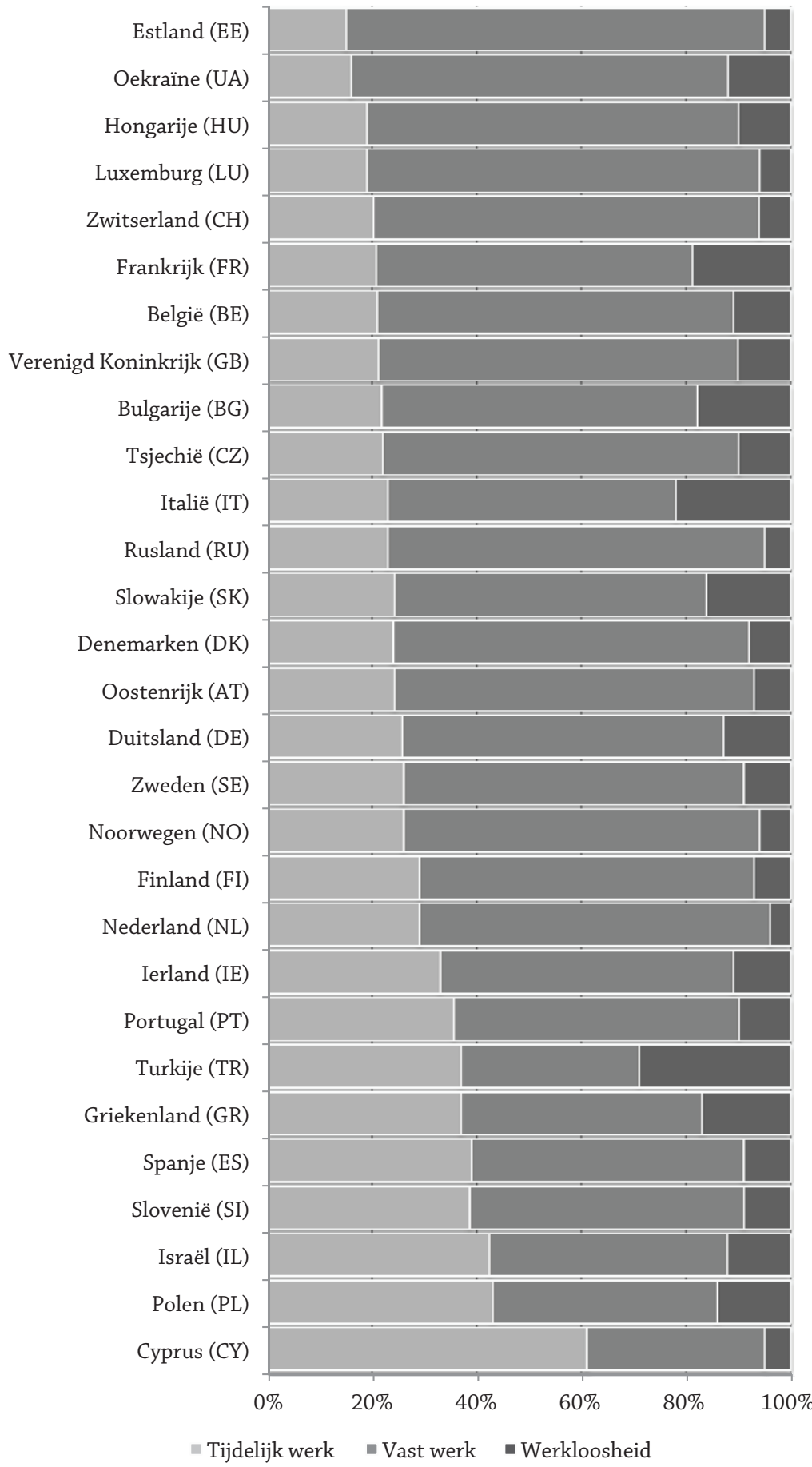


tarieven, belastingen op internationale handel (als een onderdeel van geldende inkomsten) en een index van kapitaalcontrole. De schaal om economische globalisering te meten omvat het gewicht van al deze indicatoren en is getransformeerd in een index lopend van 1 tot 100, waarbij de hogere waarden verwijzen naar een hoger niveau van economische globalisering (Dreher, 2006). De scores voor economische globalisering voor alle 29 landen in de periode 1992-2008 zijn toegevoegd aan de individuele gegevens. Het bereik van deze variabele varieert van 36,96 tot 98,87 .

Ten slotte zijn er twee institutionele factoren geoperationaliseerd. Deze macrokenmerken variëren minder tussen jaren (binnen landen) dan de cyclische en structurele factoren. Informatie over het meest recente beschikbare jaar is gebruikt als proxy in het geval de informatie van een bepaald jaar ontbrak. De beroepsgerichtheid van het onderwijssysteem heeft betrekking op het percentage leerlingen in het hoger secundair onderwijs dat beroepsonderwijs (op school; al dan niet in combinatie met een leerwerkplek) volgt. Deze cijfers zijn afkomstig van de OECD en variëren van 0 tot 59 procent. De ontslagbescherming van zittende werknemers is vastgesteld aan de hand van de algemene striktheid van werkgelegenheidsbeschermende wet- en regelgeving (employment protection legislation, EPL), ook verschaft door de OECD (Venn, 2009). ${ }^{2}$ Deze samenvattende maat geeft de moeilijkheid voor werkgevers aan om werknemers met een vast contract te ontslaan in combinatie met de beperkingen voor hen om tijdelijke werknemers in te zetten. In onze gegevens varieert deze variabele tussen 0,6 en 3,85 .

\section{Controlevariabelen}

In de multivariate analyse houden we rekening met verschillende covariaten. Allereerst is gecontroleerd voor de variabele geslacht. Daarnaast is de variabele etniciteit opgenomen, gebaseerd op informatie aangaande het geboorteland van de ouders van de respondent. Wanneer een of beide ouders van de respondent in een ander land is geboren dan waar het interview heeft plaatsgevonden, wordt deze als allochtoon beschouwd. De variabele studierichting is opgenomen om te controleren voor richtingspecifieke verschillen in werkgelegenheid voor schoolverlaters. Deze variabele verwijst naar de richting van de hoogst bereikte opleiding. De volgende categorieën zijn onderscheiden: algemeen onderwijs, technisch onderwijs, economisch onderwijs en cultureel onderwijs. ${ }^{3}$ Ten slotte is de duur sinds het verlaten van het onderwijs (in jaren variërend van 0 tot en met 10) opgenomen om de fase van het integratieproces te duiden.

\section{Resultaten}

\section{Beschrijvende analyse}

Voordat we de resultaten bespreken van de multivariate analyse, waarin de effecten van cyclische, structurele en institutionele factoren op de arbeidsmarktintegratie van jongeren zijn geschat, tonen we eerst in figuur 2 het bivariate verband tussen elk van deze contextuele factoren en de beide situaties van een gebrekkige 
arbeidsmarktintegratie (dat wil zeggen, werkloosheid en tijdelijk werk). De gepresenteerde cijfers zijn daarbij binnen landen gemiddeld over de periode 1992-2008. Uit de figuur komt naar voren dat, weinig verrassend, in landen met een hoge werkloosheid het aandeel jongeren dat werkloos is of tijdelijk werk heeft, hoger is dan in landen met een lage werkloosheid. Wat betreft globalisering zien we dat in landen waar de economie meer geglobaliseerd is, het aandeel jongeren dat werkloos is of tijdelijk werk heeft, juist lager is dan in landen die economisch gezien minder geglobaliseerd zijn. De beroepsgerichtheid van het onderwijssysteem hangt positief samen met de arbeidsmarktintegratie van jongeren: in landen waar het beroepsonderwijs sterker is vertegenwoordigd, is het aandeel jongeren dat werkloos is of tijdelijk werk heeft, lager dan in landen waar dit minder het geval is. Tot slot zien we in figuur 2 dat in landen waar zittende werknemers meer ontslagbescherming genieten, het aandeel jongeren dat werkloos is of tijdelijk werk heeft, hoger is dan in landen met weinig ontslagbescherming voor zittende werknemers.

\section{Multivariate analyse}

De waargenomen verbanden in figuur 2 zijn verder onderzocht door middel van multiniveau-analyse. In tabel 1 zijn de schattingen van 2-niveau multinomiale logit modellen weergegeven. In deze modellen wordt zowel werkloosheid als tijdelijk werk afgezet tegenover vast werk. Zoals eerder geschetst maken individuen het laagste niveau uit in de analyse (niveau 1); zij zijn genest binnen combinaties van land en jaar van schoolverlaten (niveau 2). Er zijn zes modellen geschat. In model 1 zijn alle hoofdeffecten geschat van zowel de individuele als contextuele kenmerken. Dit model maakt het mogelijk de hypothesen 1a, 2a, 3a en 4a te toetsen. In de modellen 2 tot en met 5 zijn vervolgens crossniveau-interacties opgenomen tussen het opleidingsniveau van individuen en de contextuele kenmerken. Elk contextueel kenmerk is afzonderlijk in interactie met het individuele opleidingsniveau geschat. Hiermee worden de hypothesen $1 b, 2 b, 3 b$ en $4 b$ getoetst. In model 6, tot slot, zijn alle interactietermen tegelijkertijd opgenomen.

Omdat de modelcoëfficiënten uit tabel 1 moeilijk zijn te interpreteren, hebben we ter illustratie het gemiddelde van de voorspelde kansen op tijdelijk werk, vast werk en werkloosheid voor alle individuen in onze dataset gepresenteerd in figuur 3, waarbij we landen met een lage score op een contextueel kenmerk (dat wil zeggen, landen met een score onder het gemiddelde) vergelijken met landen met een hoge score (dat wil zeggen, landen met een score van het gemiddelde of hoger). Daarbij zijn de gemiddelde kansen weergegeven op basis van de coëfficiënten uit model 1 en daarnaast de specifieke kansen voor lager, middelbaar en hogeropgeleiden op basis van de afzonderlijke interactiemodellen (model 2-5). ${ }^{4}$

Uit model 1 komt allereerst naar voren dat wanneer de algehele werkloosheid hoog is, jongeren bij intrede op de arbeidsmarkt een grotere kans op werkloosheid $(b=1,001)$ en op tijdelijk werk hebben $(b=0,316)$. Deze bevindingen komen overeen met H1a. Uit figuur 3 kunnen we afleiden dat de voorspelde kans op werkloosheid in landen met een hoog werkloosheidspercentage inderdaad 3 procent hoger ligt, maar wat betreft tijdelijk werk zijn de gemiddelde kansen nagenoeg gelijk aan elkaar en is het effect van werkloosheid dus klein. Om te bepalen 
Figuur 2 Het verband tussen conjuncturele, structurele en institutionele factoren en de arbeidsmarktintegratie van jongeren in Europa
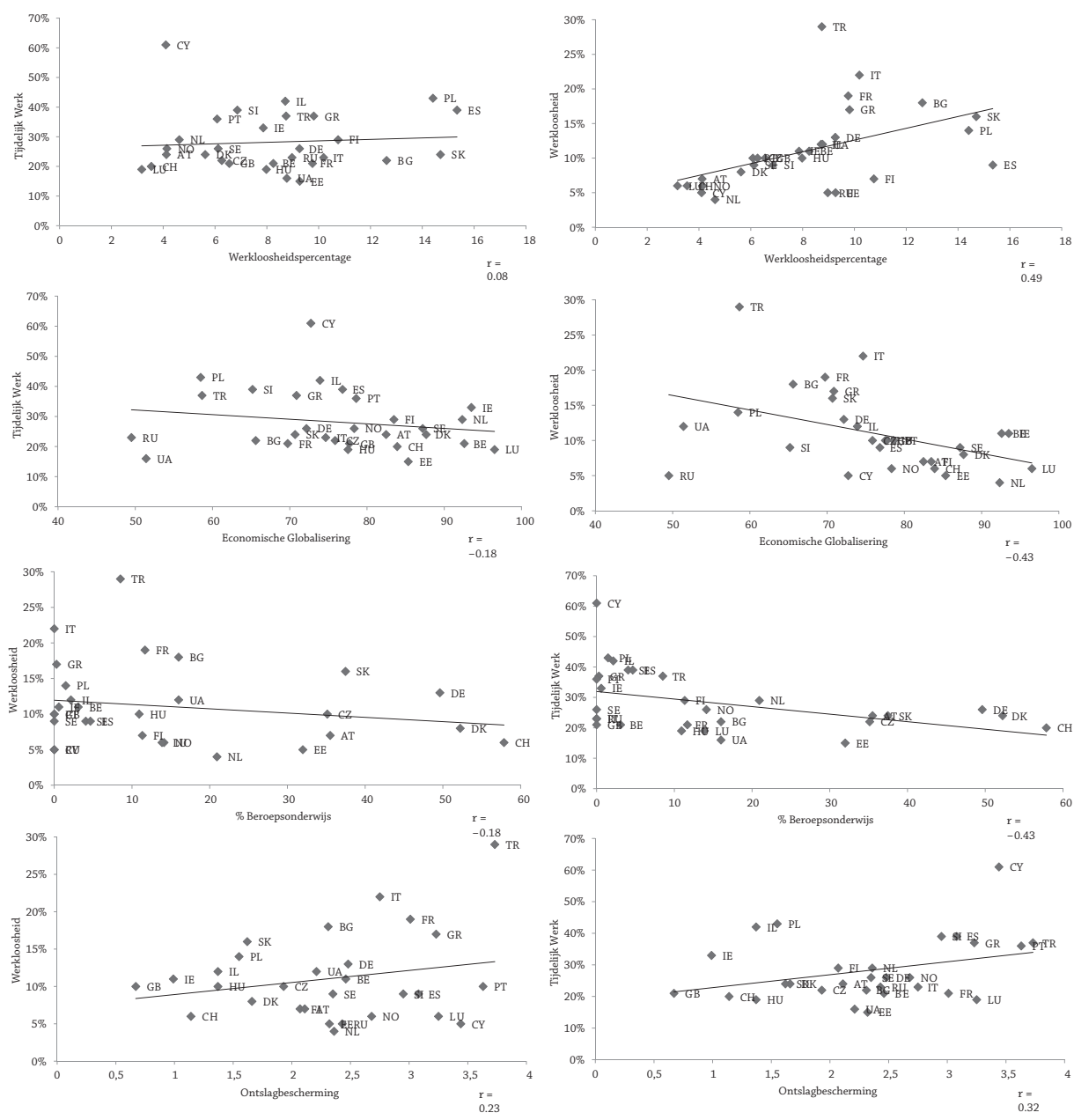

of het werkloosheidseffect in het bijzonder van toepassing is op lager opgeleide jongeren (H1b), worden in model 2 interactietermen tussen het individuele opleidingsniveau en het werkloosheidspercentage toegevoegd. Uit dit model blijkt enkel dat, tegengesteld aan onze verwachtingen, het effect van de algehele werkloosheid op de kans op tijdelijk werk significant groter is voor middelbaar dan lager opgeleide jongeren. Wat betreft het positieve effect van de algehele werkloosheid op de kans op werkloosheid, worden geen verschillen tussen jongeren met verschillende opleidingsniveaus gevonden. Figuur 3 ondersteunt deze bevindingen, waarmee we kunnen concluderen dat er geen steun gevonden wordt voor hypothese $1 b$. 
De resultaten van model 1 laten daarnaast zien dat economische globalisering een negatief effect heeft op de kans op werkloosheid en tijdelijk werk. De coëfficiënten bedragen respectievelijk -1,131 en -0,341. Met andere woorden: de arbeidsmarktintegratie van jongeren verloopt soepeler wanneer het niveau van economische globalisering hoger is. Figuur 3 toont dat enkel de gemiddelde kans op werkloosheid 3 procent lager ligt in dergelijke landen, maar het verschil in de kans op tijdelijk werk te verwaarlozen is. Deze bevindingen zijn in tegenspraak met H2a, maar in lijn met de eerder getoonde beschrijvende analyse. Uit model 3 maken we op dat het negatieve effect van economische globalisering op tijdelijk werk vooral middelbaar opgeleide jongeren treft $(b=-0,04+-0,860=-0,900)$ en dat dit effect op de kans op werkloosheid minder groot is bij hoger opgeleide jongeren $(b=$ -0.457). Deze bevindingen worden ondersteund door figuur 3, maar ondersteunen $\mathrm{H} 2 \mathrm{~b}$ niet. Figuur 3 toont verder dat, hoewel de coëfficiënt van economische globalisering voor de kans op tijdelijk versus vast werk voor lager opgeleiden niet significant is (en daarnaast negatief), de kans op tijdelijk werk in landen met een hoge mate van globalisering voor lager opgeleiden 5 procent hoger ligt dan in minder geglobaliseerde landen. Deze bevinding ondersteunt H2b wel, maar kan niet met zekerheid worden aangenomen.

Model 1 toont verder dat de beroepsgerichtheid van het onderwijssysteem de arbeidsmarktintegratie van jongeren bevordert. Gevonden is dat de kans op werkloosheid, maar met name de kans op tijdelijk werk voor jongeren lager is naarmate er in het onderwijssysteem meer aandacht is voor beroepsonderwijs, zoals ook zichtbaar is in figuur 3 (het verschil in de gemiddelde kans op tijdelijk werk tussen landen met weinig en veel aandacht voor het beroepsonderwijs is 7 procent). Dit is in overeenstemming met H3a. Bovendien ondersteunen de resultaten in model 4 de voorspelling dat vooral (middelbaar) en hoger opgeleide jongeren profijt hebben van een beroepsgericht onderwijssysteem (H3b). Model 4 maakt nog iets duidelijk: het effect van een beroepsgericht onderwijssysteem op de kans op tijdelijk werk is zelfs positief voor laag opgeleide jongeren $(b=0,574)$. Dit houdt in dat zij voor wat betreft hun arbeidsmarktintegratie nadeel ondervinden van een onderwijssysteem dat de nadruk legt op beroepsgerichte kennis en vaardigheden. Dit zien we ook terug in figuur 3: de kans op tijdelijk werk ligt maar liefst 11 procent hoger in landen met veel aandacht voor het beroepsonderwijs, ten opzichte van landen met weinig aandacht hiervoor, terwijl diezelfde kans voor middelbaar opgeleiden 12 procent en voor hoger opgeleiden 7 procent lager ligt. De verschillen tussen lager versus middelbaar en hoger opgeleiden in de kans op tijdelijk werk zijn dus vrij groot in landen met veel aandacht voor beroepsonderwijs.

Tot slot wordt duidelijk uit model 1 dat de ontslagbescherming van zittende werknemers de arbeidsmarktintegratie van jongeren ondermijnt. De bevindingen laten immers zien dat de kans op werkloosheid en de kans op tijdelijk werk voor jongeren groter zijn naarmate de rechtspositie van zittende werknemers beter is beschermd, hoewel deze verschillen klein zijn volgens figuur 3. De geschatte coëfficiënten zijn respectievelijk 0,291 en 0,396. Deze resultaten bevestigen H4a. Vooral hoger opgeleide jongeren hebben een grotere kans op werkloosheid wan- 
neer zittende werknemers zijn beschermd tegen ontslag. Deze bevinding is in overeenstemming met $\mathrm{H} 4 \mathrm{~b}$.

In model 6 zijn alle interactietermen tegelijkertijd geschat om de robuustheid van de modellen 2 tot en met 5 te bepalen. De resultaten van dit model laten - alleen voor wat betreft de kans op tijdelijk werk - enkele verschillen zien. Zo blijkt nu dat de interactieterm tussen de algehele werkloosheid en een middelbaar opleidingsniveau niet langer (marginaal) significant is, terwijl de interactie tussen werkloosheid en een hoog opleidingsniveau juist (marginaal) significant wordt. Volgens deze resultaten zijn het dus vooral hoger opgeleide jongeren die minder nadeel ondervinden van een hoge werkloosheid bij de kans op tijdelijk werk. Ze sluiten meer aan bij H1b dan de bevindingen zoals getoond in model 2. Daarnaast komt uit model 6 naar voren dat, in vergelijking met model 3, de interactie tussen economische globalisering en een middelbaar opleidingsniveau niet meer significant is. Een aannemelijke verklaring hiervoor is dat de verschillen in de kans op tijdelijk werk op basis van economische globalisering gedeeltelijk samenhangen met verschillen die tot stand komen door de mate van aandacht voor het beroepsonderwijs in een land, aangezien beide contextuele kenmerken licht positief samenhangen, zoals blijkt uit Bijlage II. 


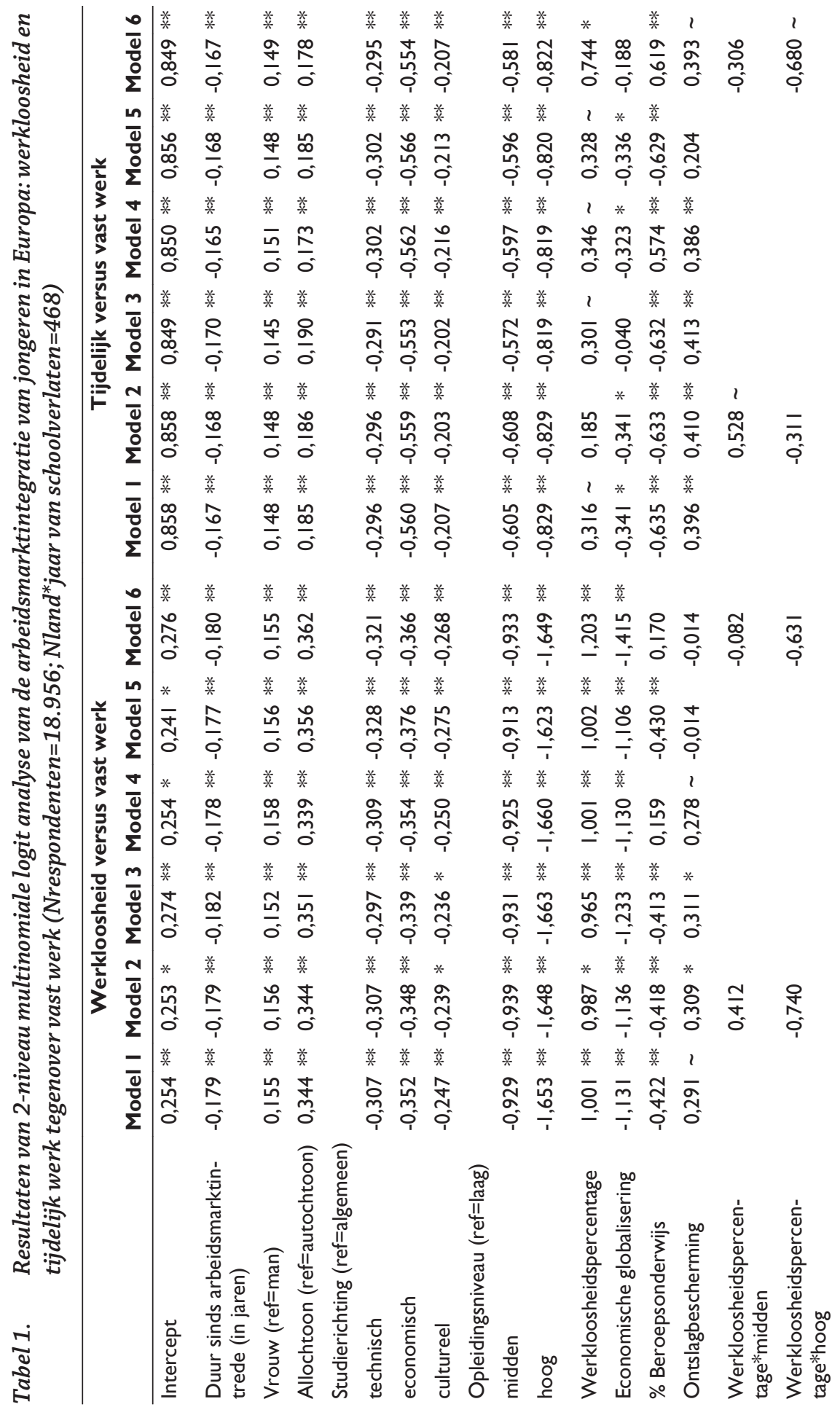




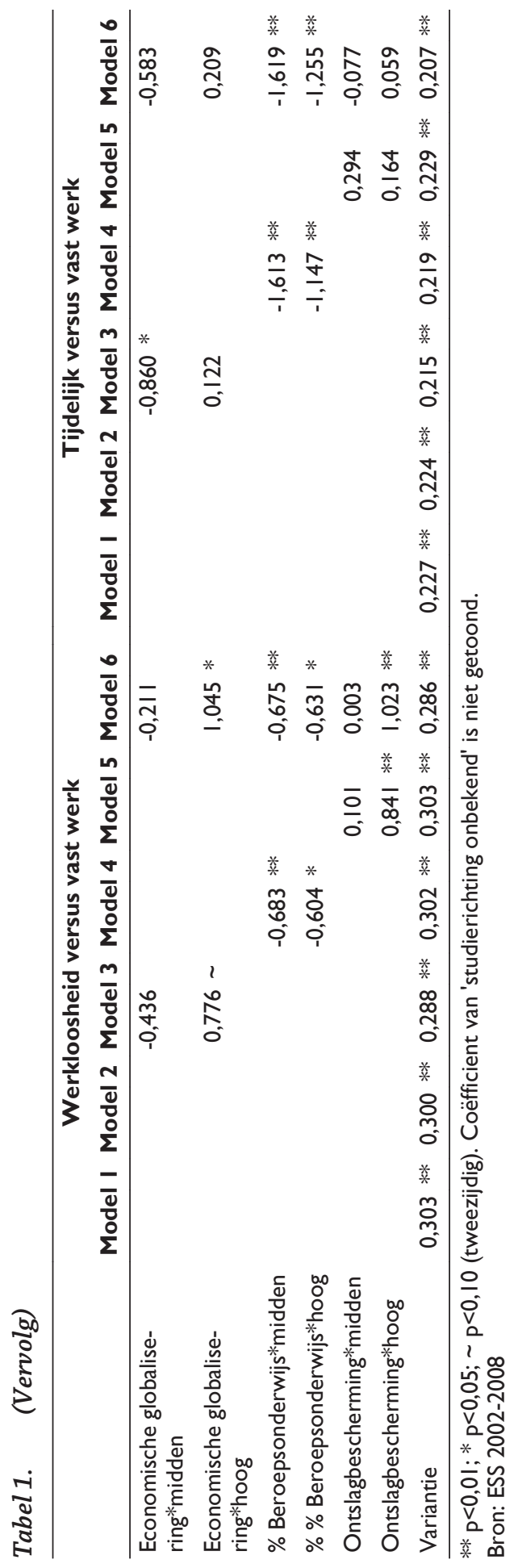


Figuur 3 De voorspelde kans op tijdelijk werk, vast werk en werkloosheid voor jongeren in landen met lage versus hoge scores op conjuncturele, structurele en institutionele factoren

Werkloosheidspercentage

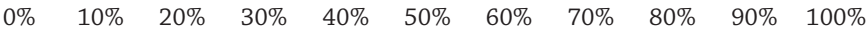

\begin{tabular}{|c|c|c|c|}
\hline Gemiddeld & 0,28 & 0,63 & 0,09 \\
\hline Lager opgeleiden & 0,37 & 0,45 & 0,19 \\
\hline Middelbaar opgeleiden & 0,27 & 0,63 & 0,10 \\
\hline Hoger opgeleiden & 0,26 & 0,68 & 0,06 \\
\hline Gemiddeld & 0,28 & 0,60 & 0,12 \\
\hline Lager opgeleiden & 0,37 & 0,42 & 0,22 \\
\hline Middelbaar opgeleiden & 0,30 & 0,57 & 0,13 \\
\hline Hoger opgeleiden & 0,25 & 0,69 & 0,07 \\
\hline
\end{tabular}

= Tijdelijk werk $\quad$ - Vast werk $\quad$ Werkloosheid

Economische globalisering

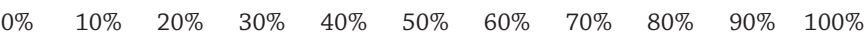

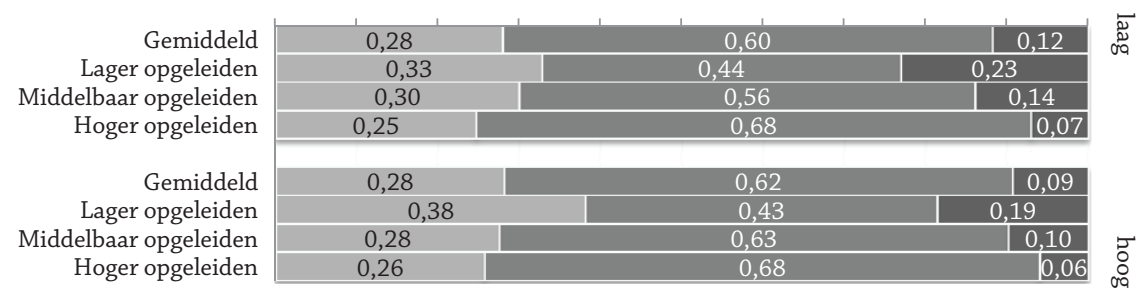

= Tijdelijk werk $\quad$ - Vast werk $\quad$ Werkloosheid

$\%$ Beroepsonderwijs

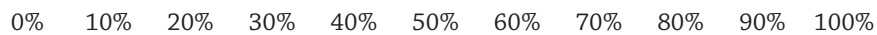

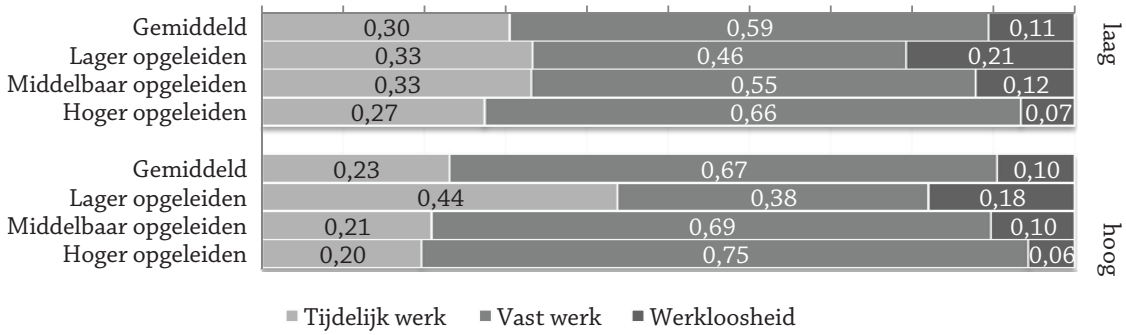

Ontslagbescherming

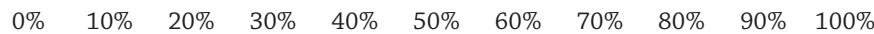

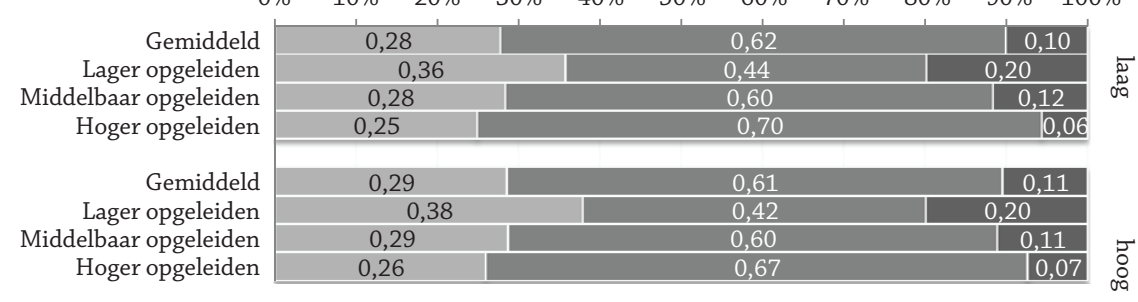

घijdelijk werk $\quad$ Vast werk $\quad$ Werkloosheid 


\section{Conclusie en discussie}

De empirische resultaten van dit artikel hebben laten zien dat cyclische, structurele en institutionele factoren verschillen in de arbeidsmarktintegratie van jongeren tussen Europese landen verklaren. Voor wat betreft de invloed van de conjuncturele cyclus geldt dat wanneer de werkloosheid hoog is, de arbeidsmarktintegratie van jongeren minder soepel verloopt. Dit uit zich niet alleen in een grotere kans op werkloosheid, maar ook in een grotere kans op tijdelijk werk. Desalniettemin lijken deze effecten, met name wat betreft de kans op tijdelijk werk, vrij marginaal. Er zijn ook aanwijzingen gevonden dat hoger opgeleide jongeren minder kwetsbaar zijn voor tijdelijk werk wanneer zij onder ongunstige macroeconomische omstandigheden de arbeidsmarkt voor het eerst betreden, dan lager opgeleide jongeren. Dit lijkt het idee te ondersteunen dat werkgevers vooral arbeidsmarktonzekerheid overdragen op lager opgeleiden, die gemakkelijker onderworpen kunnen worden aan directe supervisie en gemakkelijker vervangen kunnen worden dan hoger opgeleiden.

Als structurele factor werd de invloed van economische globalisering onderzocht. De voorspelling was dat een hoger niveau van economische globalisering zou leiden tot groeiende mondiale competitie tussen bedrijven en tot een toenemende onzekerheid voor werkgevers. Dit zou hen dwingen (meer) flexibele arbeidsrelaties aan te gaan bij het werven van (nieuw) personeel. Onze bevindingen suggereren echter het tegenovergestelde resultaat, namelijk dat de arbeidsmarktintegratie van jongeren soepeler verloopt wanneer de economie een hoger niveau van globalisering kent. Hoewel onverwacht zijn deze resultaten toch minder onbegrijpelijk als er wat langer over wordt nagedacht. Zo pleit Golsch (2008, p. 32) dat economische stromen, als een van de twee dimensies van economische globalisering, zowel aangeven hoe goed de nationale economie groeit als hoe goed deze economie geïntegreerd is in de mondiale economische uitwisseling. Op deze manier uitgelegd kan een positieve invloed worden verwacht van economische globalisering op de arbeidsmarktintegratie van jongeren.

Beide onderzochte institutionele factoren, ten slotte, zijn ook van belang bij het verklaren van crossnationale verschillen in de arbeidsmarktintegratie van jongeren. Onze bevindingen zijn het meest duidelijk voor wat betreft de inrichting van het onderwijssysteem: hoe meer beroepsgericht het onderwijssysteem, des te soepeler is de integratie van jongeren op de arbeidsmarkt. Wij moeten hier echter aan toevoegen dat het voordeel van een beroepsgericht onderwijssysteem in hoofdzaak geldt voor jongeren die zelf in het bezit zijn van een diploma in het middelbaar of hoger (beroeps)onderwijs. De keerzijde hiervan is dat lager opgeleide jongeren, die nauwelijks zijn voorbereid op de beroepspraktijk, juist de boot missen in een context waar een nauwe band bestaat tussen het onderwijs en de arbeidsmarkt. Ook de resultaten met betrekking tot de rechtspositie van zittende werknemers zijn eenduidig. Aangetoond is dat de arbeidsmarktintegratie van jongeren enigszins moeizamer verloopt naarmate zittende werknemers sterker beschermd zijn tegen ontslag. Voor wat betreft de kans op werkloosheid is dit effect het grootst voor hoger opgeleide jongeren, die vooral gericht zijn op het pri- 
maire segment van de arbeidsmarkt waar werkgelegenheidsbeschermende wet- en regelgeving meestal strikt is.

Gezien deze bevindingen liggen verschillende beleidsmaatregelen voor de hand. Allereerst is het van belang om de band tussen onderwijs en arbeidsmarkt sterker te maken, door het introduceren of uitbreiden van beroepsgericht onderwijs. Werkgevers geven vaak de voorkeur aan een goed getrainde stagiair, dan aan een afgestudeerde zonder werkervaring. In landen met een uitgebreid duaal stelsel, waarin praktische ervaring op de werkvloer wordt gecombineerd met theoretisch onderwijs op school, is de kans op werkloosheid of tijdelijk werk kleiner. Duitsland, Oostenrijk en Nederland vormen hier een goed voorbeeld voor. Wel lijkt het van belang om ervoor te zorgen dat er ook voldoende stage- of werkervaringsplekken beschikbaar zijn voor lager opgeleiden, aangezien zij juist vaker in tijdelijk werk terechtkomen in landen met een sterk beroepsgericht onderwijssysteem. Ten tweede draagt een versoepeling van het ontslagrecht bij aan het bevorderen van de arbeidsmarktintegratie van jongeren. Nu worden de kansen voor jongeren ondermijnd door de (meestal) sterke ontslagbescherming van zittende werknemers. Naast de onzekerheid die dit bij intrede op de arbeidsmarkt met zich meebrengt, heeft een moeizame arbeidsmarktintegratie mogelijk verstrekkende gevolgen voor het verdere leven van jongeren, zowel voor toekomstige arbeidsmarktkansen, alsook voor terreinen als gezinsvorming en sociale participatie, bijvoorbeeld. Keerzijde van het vervangen van oudere werknemers door jongeren is evenwel dat het leidt tot een grotere kans op werkloosheid van ouderen, omdat de prikkel voor werkgevers om in de duurzame inzetbaarheid van hun oudere werknemers te investeren, wordt verlaagd. Het staat bovendien haaks op het vigerende beleid oudere werknemers langer aan het werk te houden om zo uitgaven aan pensioenen en andere uitkeringen enigszins onder controle te houden. Het leidt er echter wel toe dat in de nabije toekomst een mogelijk verloren generatie van jongeren kan worden voorkomen.

\section{Noten}

1 De combinatie van land en jaar van schoolverlaten (in plaats van land) is gebruikt als het hogere analyseniveau om meer onderscheidingsvermogen te verkrijgen voor het statistisch toetsen van de hypothesen en om zo veel mogelijk ruimte te laten voor de aanwezige variatie tussen jaren binnen landen. Door convergentieproblemen kunnen we helaas geen 3-niveaumodellen (met individuen [niveau 1] genest in land*jaar van schoolverlaten combinaties [niveau 2] genest in landen [niveau 3]) presenteren.

2 De gegevens voor BG en SI over de periode 1992-2000 zijn afkomstig van Cazes en Nesporova (2003); die voor de periode 2001-2004 van Tonin (2009). Van Muravyev (2010) hebben we de cijfers voor EE, RU en UA gebruikt. Voor IL en LU zijn de cijfers van de OECD uit 2008 voor de gehele onderzochte periode gebruikt. Voor CY, tot slot, waren geen afzonderlijke cijfers beschikbaar en is het gemiddelde van de scores van GR en TR toegepast.

3 In 2002 is geen informatie over studierichting gevraagd in het ESS. Daarom is een dummyvariabele in de modellen opgenomen (niet gerapporteerd) die aangeeft of 
informatie over de studierichting van de hoogst bereikte opleiding al dan niet ontbreekt voor respondenten.

4 Wij danken Rob Eisinga, hoogleraar bij de sectie Sociologie, Radboud Universiteit Nijmegen, voor zijn hulp bij het inzichtelijk maken van deze gegevens.

\section{Literatuur}

Allmendinger, J. (1989). Educational systems and labour market outcomes. European Sociological Review, 5, 231-250.

Berman, E., Bound, J. \& Machin, S. (1998). Implications of skill-biased technological change: International evidence. The Quarterly Journal of Economics, 113, 1245-1279.

Blanchard, O. (2006). European unemployment: The evolution of facts and ideas. Economic Policy, 21, 5-59.

Blossfeld, H.-P. (1992). Is the German dual system a model for a modern vocational training system? A cross-national comparison of how different systems of vocational training deal with the changing occupational structure. International Journal of Comparative Sociology, 23, 168-181.

Blossfeld, H.-P. Buchholz, S., Bukodi, E. \& Kurz, K. (eds.) (2008). Young workers, globalization and the labor market: Comparing early working life in eleven countries. Cheltenham, UK/Northampton, MA: Edward Elgar.

Bol, T. \& Werfhorst, H. van de (2013). Educational systems and the trade-off between labor market allocation and equality of educational opportunity. Comparative Education Review, 57, (2) 285-308.

Borghans, L. \& Grip, A. de (eds.) (2000). The overeducated worker? The economics of skill utilization. Cheltenham, UK/Northampton, MA: Edgar Elgar.

Breen, R. (1997). Risk, Recommodification and the Future of the Service Class. Sociology, 31, 473-489.

Breen, R. (2005). Explaining cross-national variation in youth unemployment. Market and institutional factors. European Sociological Review, 21, 125-134.

Buchholz, S., Hofäcker, D., Mills, M., Blossfeld, H.-P., Kurz, K. \& Hofmeister, H. (2009). Life courses in the globalization process: The development of social inequalities in modern societies. European Sociological Review, 25, 53-71.

Bukodi, E., Ebralidze, E., Schmelzer, P. \& Blossfeld, H.-P. (2008). Struggling to become an insider: Does increasing flexibility at labor market entry affect early careers? In H.-P. Blossfeld, S. Buchholz, E. Bukodi \& K. Kurz (eds.), Young workers, globalization and the labor market: Comparing early working life in eleven countries (pp. 3-27). Cheltenham, UK/Northampton, MA: Edward Elgar.

Castells, M. (1996). The rise of the network society. The information age: economy, society, and culture, Volume I. Oxford/Malden, MA: Blackwell.

Cazes, S. \& Nesporova, A. (2003). Employment protection legislation (EPL) and its effects on labour market performance. Geneva: International Labour Organization.

Delsen, L. \& de Jong, E. (1997). Het wankele mirakel. Economisch Statistische Berichten, 82(4103), 324-327.

Dreher, A. (2006). Does globalization affect growth? Evidence from a new index of globalization. Applied Economics, 38, 1091-1110.

Gangl, M. (2002). Changing labour markets and early career outcomes: Labour market entry in Europe over the past decade. Work, Employment and Society, 16, 67-90. 
Gesthuizen, M. \& Wolbers, M.H.J. (2010). Employment transitions in the Netherlands, 1980-2004: Are low educated men subject to structural or cyclical crowding out? Research in Social Stratification and Mobility, 28, 437-451.

Golsch, K. (2008). Youth unemployment in Western Europe; The effects of individual, market, and institutional factors. In H.-P. Blossfeld, S. Buchholz, E. Bukodi \& K. Kurz (eds.), Young workers, globalization and the labor market. Comparing early working life in eleven countries (pp. 29-47). Cheltenham, UK/Northampton, MA: Edward Elgar.

Grip, A. de \& Wolbers, M.H.J. (2006). Cross-national differences in job quality among lowskilled young workers in Europe. International Journal of Manpower, 27, 420-433.

Hannan, D., Raffe, D. \& Smyth, E. (1997). Cross-national research on school to work transitions: An analytical framework. In P. Werquin, R. Breen \& J. Planas (eds.), Youth transitions in Europe: Theory and evidence (pp. 409-442). Marseille: Centre d'études et de recherches sur les qualifications.

Jowell, R., The Central Co-ordinating Team (2003). European Social Survey 2002/2003: Technical report. London: Centre for Comparative Social Surveys, City University.

Jowell, R., The Central Co-ordinating Team (2005). European Social Survey 2004/2005: Technical report. London: Centre for Comparative Social Surveys, City University.

Jowell, R., The Central Co-ordinating Team (2007). European Social Survey 2006/2007: Technical report. London: Centre for Comparative Social Surveys, City University.

Jowell, R., The Central Co-ordinating Team (2009). European Social Survey 2008/2009: Technical report. London: Centre for Comparative Social Surveys, City University.

Kalleberg, A.L. (2009). Precarious work, insecure workers: Employment relations in transition. American Sociological Review, 74, 1-22.

Katz, L.F. \& Autor, D.H. (1999). Changes in the wage structure and earnings inequality. In O. Ashenfelter \& D. Card (red.), Handbook of labor economics: Vol. 3 (pp. 1463-1555). Amsterdam: North-Holland.

Kogan, I., Noelke, C. \& Gebel, M. (eds.) (2011). Making the transition: Education and labor market entry in Central and Eastern Europe. Stanford, CA: Stanford University Press.

Lange, M. de, Gesthuizen, M. \& Wolbers, M.H.J. (2012). Trends in labor market flexibilization among Dutch school-leavers: The impact of economic globalization on educational differences. International Sociology, 27, 529-550.

Lindbeck, A. \& Snower, D. (1988). The insider-outsider theory of employment and unemployment. Cambridge, MA: MIT Press.

Maurice, M. \& Sellier, F. (1979). Societal analysis of industrial relations: A comparison between France and West Germany. British Journal of Industrial Relations, 17, 322-336.

Mills, M. \& Blossfeld, H.-P. (2005). Globalization, uncertainty and the early life course: A theoretical framework. In H.-P. Blossfeld, E. Klijzing, M. Mills \& K. Kurz (eds.), Globalization, uncertainty and youth in society (pp. 1-24). London/New York: Routledge.

Müller, W. \& Gangl, M. (2003). The transition from school to work. A European perspective. In W. Müller \& M. Gangl (red.), Transitions from education to work in Europe. The integration of youth into EU labour markets (pp. 1-22). Oxford: Oxford University Press.

Muravyev, A. (2010). Evolution of employment protection legislation in the USSR, CIS and Baltic States, 1985-2009. IZA Discussion Paper No. 5365. Bonn: Institute for the Study of Labor.

OECD (1999). Employment outlook. Paris: Organisation of Economic Co-operation and Development.

OECD (2000). From initial education to working life: Making transitions work. Paris: Organisation for Economic Co-operation and Development.

OECD (2012). Employment policies and data. Paris: Organisation for Economic Co-operation and Development. 
Pollmann-Schult, M. (2005). Crowding-out of unskilled workers in the business cycle: Evidence from West Germany. European Sociological Review, 21, 467-480.

Scherer, S. (2005). Patterns of Labour Market Entry - Long Wait or Career Instability? An Empirical Comparison of Italy, Great Britain and West Germany. European Sociological Review, 21(5), 427-440.

Shavit, Y. \& Müller, W. (1998). From school to work: A comparative study of educational qualifications and occupational destinations. Oxford: Clarendon Press.

Steijn, B., Need, A. \& Gesthuizen, M. (2006). Well begun, half done? Long-term effects of labour market entry in the Netherlands, 1950-2000. Work, Employment and Society, 20, 453-472.

Tonin, M. (2009). Employment protection legislation in Central and East European countries. South-East Europe Review, 4, 477-491.

Velden, R.K.W. van der \& Wolbers, M.H.J. (2003). The integration of young people into the labour market: The role of training systems and labour market regulation. In W. Müller \& M. Gangl (eds.), Transitions from education to work in Europe: The integration of youth into EU labour market (pp. 186-211). Oxford: Oxford University Press.

Venn, D. (2009). Legislation, collective bargaining and enforcement: Updating the OECD employment protection indicators. Paris: Organisation for Economic Co-operation and Development.

Vreyer, Ph. De, Layte, R., Wolbers, M.H.J. \& Hussain, A. (2000). The permanent effects of labour market entry in times of high unemployment. In D. Gallie \& S. Paugam (eds.), Welfare regimes and the experience of unemployment in Europe (pp. 134-152). Oxford: Oxford University Press.

Wolbers, M.H.J. (2007). Patterns of labour market entry: A comparative perspective on school-to work transitions in 11 European countries. Acta Sociologica, 50, 189-210. 
Bijlage I Conjuncturele, structurele en institutionele factoren per land: N, minimum, maximum en gemiddelde waarde

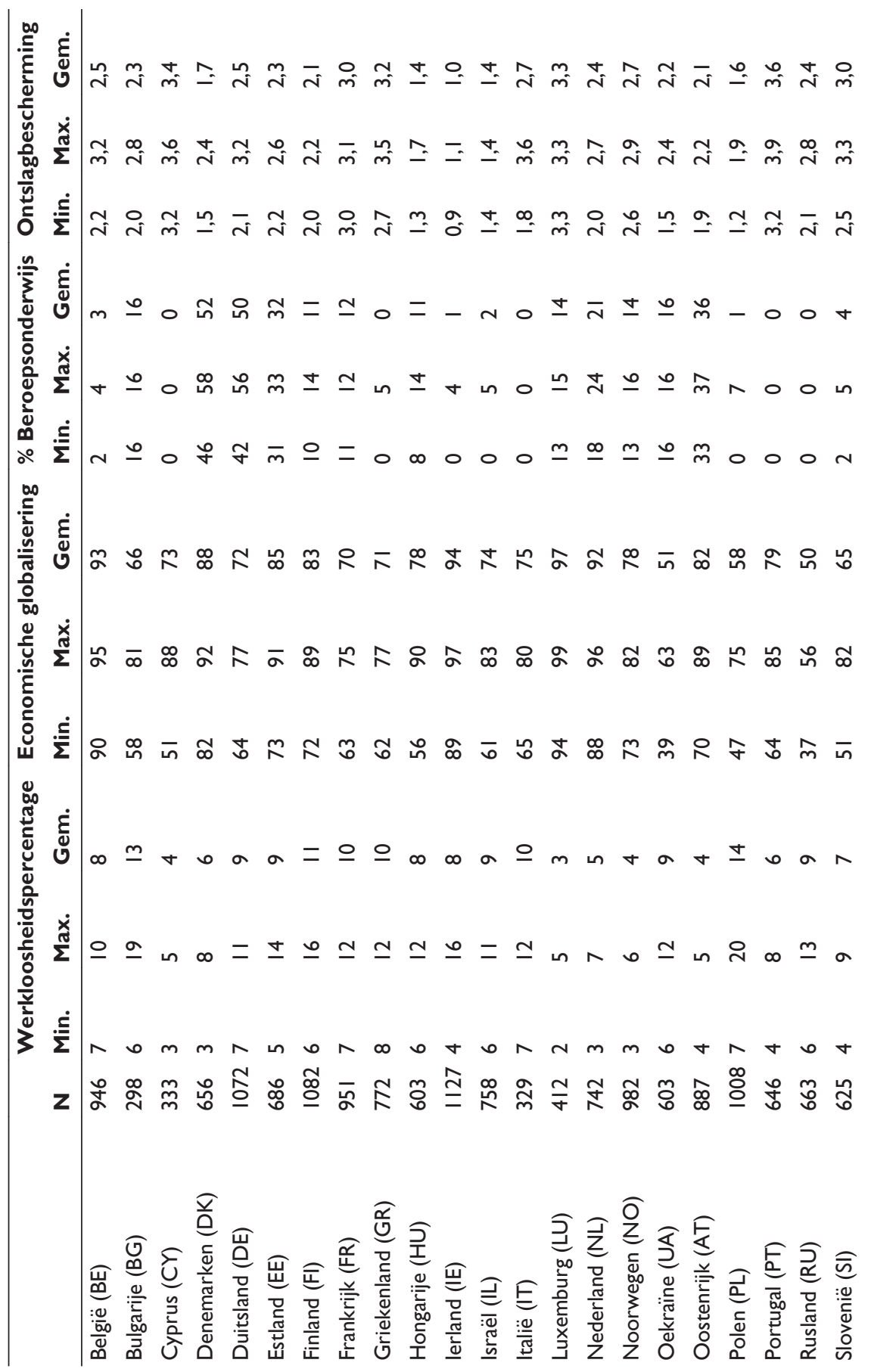




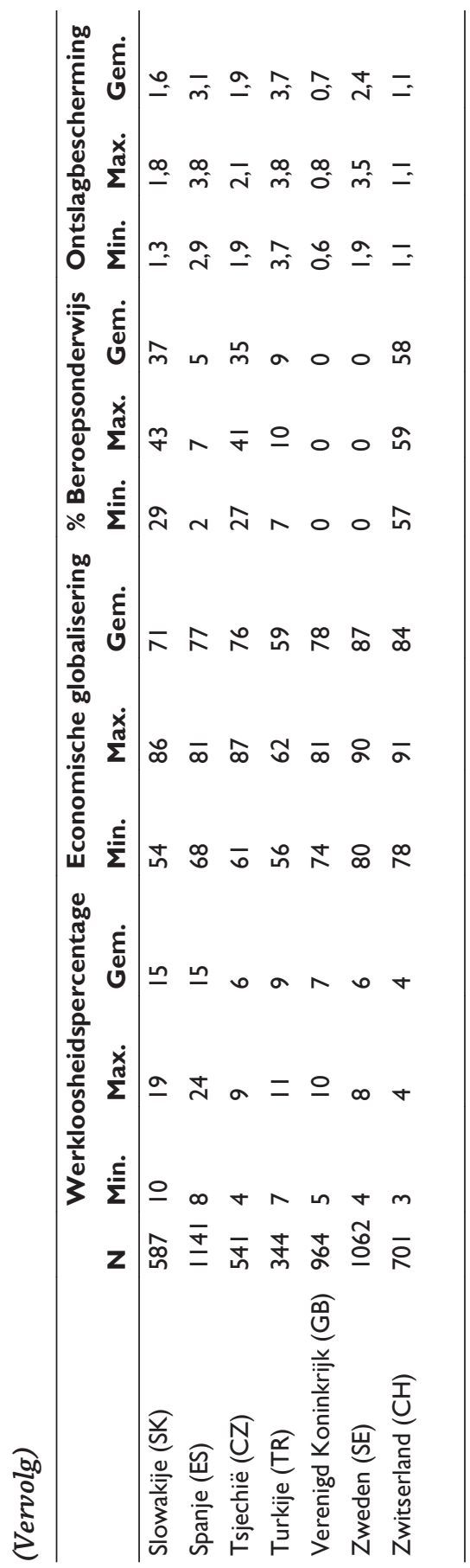


Bijlage II Correlatiematrix van conjuncturele, structurele en institutionele factoren

\begin{tabular}{lllll}
\hline & $\begin{array}{l}\text { Werkloos- } \\
\text { heidspercen- } \\
\text { tage }\end{array}$ & $\begin{array}{l}\text { Economische } \\
\text { globalisering }\end{array}$ & $\begin{array}{l}\text { \% Beroeps- } \\
\text { onderwijs }\end{array}$ & $\begin{array}{l}\text { Ontslag- } \\
\text { bescher- } \\
\text { ming }\end{array}$ \\
\hline Werkloosheidspercentage & $\mathrm{I}$ & & & \\
Economische globalisering & $-0,399^{* *}$ & $\mathrm{I}$ & & \\
\% Beroepsonderwijs & $-0,169^{* *}$ & $0,162^{* *}$ & $\mathrm{I}$ & \\
Ontslagbescherming & 0,016 & $-0,195^{* *}$ & $-0,250^{* *}$ & $\mathrm{I}$ \\
\hline
\end{tabular}

